\title{
Community as a theological motif for evangelical theology ${ }^{1}$
}

Stanley J. Grenz

Department of Theology and Ethics

Carey Theological College/Regent College

Vancouver

CANADA

\begin{abstract}
A crucial task for Western theologians in our day is to discover an integrative motif that can assist in constructing a systematic theology that takes seriously both our particular context and the phenomenon of globalization. Since Schleiermacher, the most influential integrative motif in theology has been the kingdom of God. Although this concept is helpful, it cannot serve as the needed integrative motif, because it has been taken captive by Western individualism.

The new communitarian thinkers offer a helpful alternative, the concept of community. The establishment of community is central to the entire biblical drama, and it summarizes the final goal of the triune God in salvation history. Although community arrives in its fullness only at the consummation, it is already present among us in a partial manner. The primary focus of community is the fellowship of Christ's followers - the church as it fulfils its mandate of worship, edification, and outreach. The church is community likewise as it transmits the redemptive story through biblical proclamation and in the sacraments.

Because it provides the concept of the kingdom of God with its proper content, community offers promise as an integrative motif for a renewed evangelical theology.
\end{abstract}

\section{Introduction}

At the end of the twentieth century the church of Jesus Christ is confronted with the task of articulating the gospel in what appears to be a radically altered situation. At the heart of the context in which we seek to be the people of God is a new reality often referred to as globalization. Of course, globalization is an

1 This essay is based on chapter 6 of the author's lengthier work (Grenz, 1993) A similar form was also publishod earlier (Grenz, 1992a) 
illusive term; it can carry various meanings virtually at the whim of the speaker. But whatever else it signifies, globalization refers to the planetary consciousness characteristic of our age.

The planetary consciousness sensed by an increasing number of persons is warranted, for to some extent it is an accurate reflection of an important contemporary reality. All the peoples of the world are connected to each other and to the earth that sustains them in a manner not sensed as keenly in the past. Although we can never shed our particular location, no longer can we view ourselves merely as citizens of a region or a nation that exists only to, and for itself. Rather, we must come to grips with the fact that we are citizens both of a localized place as well as of the planet - the one earth that sustains us and the one world in which we participate.

Globalization, understood as the new planetary consciousness and the connectedness of all people everywhere on the one earth, raises an acute challenge for Western evangelical theology. What theological outlook can best serve the church in the West? What theology can facilitate a genuine realization that we participate in one church, while pointing the way as we seek to respond to the pressing needs associated with our own particularity within the context of the new global reality?

Central to the theological enterprise is the task of assisting the people of God in articulating the gospel message in the cultural context in which they are living. Theology seeks to facilitate the church in reflecting on the meaning of the gospel and in encoding that gospel in categories that can speak to the contemporary situation. To this end a systematic theology uses what may be called an 'integrative motif - a concept which serves as its central organizational structure in terms of which the various theological doctrines are developed. This motif provides the integrative thematic perspective in the light of which all other theological concepts are understood and given their relative meaning or value (Sauter $\&$ Syock, 1976:18-19).

Theological history has witnessed the devising of many integrative motifs. Martin Luther focused on justification by faith. John Calvin elevated the theme of the glory of God. John Wesley was captivated by the idea of responsible grace (see Maddox, 1984:12-18). Friedrich Schleiermacher worked from human religious experience, and Karl Barth centered on the self-disclosure of the triune God to the human person.

The search for an appropriate theological motif has retained its pull even today, despite the passing of the great system builders of the past. In fact, contemporary thinkers offer a panorama of suggestions for an adequate integrative theological motif. Twentieth century evangelicals have tended to look to the dispensations of salvation history (Chafer, 1947-1948) or to the doctrine of scripture (Erickson, 1983-1985). In mainline circles, the process philosophy of Whitehead has been 
influential throughout much of the twentieth century (Suchocki, 1984; Cobb, 1965). Among the most widely employed themes in recent decades has been that of liberation, which was originally sounded by black American (Cone, 1970) and by Latin American (Gutierrez, 1980) activist theologians. In addition, the experience of women functions as the organizing principle for feminist theology (Ruether, 1983). Furthermore narrative theology, which emphasizes personal histories and the Bible as story, has gained considerable attention, even among evangelicals (Stroup, 1973; see also Goldberg, 1982 and Fackre, 1984)

Which of these, if any, can serve the needs of a theology that takes seriously both the immediate context and the phenomenon of globalization?

\section{The kingdom of God as a theological motif}

Of the various themes cited above, none has been as widely disseminated in the twentieth century, whether in mainline theology or within evangelicalism, as the concept of the kingdom of God. ${ }^{2}$ It has been directly influential as the integrative motif for several theological proposals and indirectly important as the underlying theme behind several theological movements including the theology of hope and liberation theology. In fact, to some extent the story of twentieth century theology has been the tale of the development of theologies of the kingdom of God.

The modem interest in the development of a kingdom theology may be traced to Friedrich Schleiermacher's assertion that religion primarily has to do with what he called God-consciousness. Because Jesus enjoyed a full God-consciousness, Schleiermacher argued, our Lord is able to bring us into a vital relationship with God. This shared God-consciousness, in tum, marks us as a society of Jesus' disciples, the church, which Schleiermacher and his followers (including Albrecht Ritschl and Adolf von Harnack) linked to the kingdom of God. The apex of this liberal understanding of the kingdom came in the social gospel movement. Walter Rauschenbusch and other proponents declared that for Jesus the kingdom of God is an earthly society in which humans live together in cooperation, love and justice. The task of the social gospellers was to cooperate with God in the construction of this ideal society (for a short summary of the social gospel movement, see Hordern, 1968:85-86).

But even while Rauschenbusch was delineating the implications of the liberal understanding of the kingdom of God, its theoretical foundations were being eroded by the rediscovery of the apocalyptic element in the Bible. In his monumental book, Jesus' Proclamation of the Kingdom of God (1892), Johannes Weiss asserted that Jesus' concept of the kingdom was that of an eschatological in-

2

As an example of the widespread influence of this concept, see the doctinnal disserzation of the general secretary of the World Council of Churches (sec Castro, 1985) 
breaking of God into history. Consequently, because Jesus stood in the tradition of the ancient apocalypticists, he did not resemble the liberal ethical moralists of nineteenth century Europe.

By the middle of the century, the debate spawned by Weiss and his critics was resolved. New Testament scholars came to agree that in Jesus' mind the kingdom of God was both present and future - already and not yet - and it was both an event and a sphere of existence. Systematicians employed the findings of their New Testament colleagues to develop kingdom theologies. Through his proclamation of the rulership of God, his decisive battle against the forces of evil, and his provision of reconciliation and life for human beings, they taught, Jesus himself had inaugurated the kingdom. Yet the consummation of the reign of God remains future. The power of the 'age to come' has broken into history and is therefore present, but we will not experience its fullness until the end of the age.

These developments in the wider theological world found their parallels within evangelicalism. The twentieth century witnessed the increased influence of dispensationalism, with its orientation to a future, millennial kingdom. After midcentury, however, the already/not yet consensus was introduced into conservative circles by the Fuller Seminary New Testament scholar, George Eldon Ladd. Recently amillennialist (e.g. Hoekema, 1979) and dispensationalist (e.g. Blaising \& Bock, 1992) scholars have converged on a viewpoint similar to Ladd's position, agreeing that the kingdom is both present and future (Grenz, 1992b).

In recent years, the older consensus has begun to give way to a newer understanding that has deepened the insights of the already/not yet view (Berg, 1987:378-380). Certain thinkers now argue that the phrase the kingdom of God points to the self-disclosure of God, 'God in strength' (Chilton, 1987:287-288), or the sovereign activity of God (Chilton, 1984:25). It is the ultimate intervention of God in human affairs. The coming of the kingdom, consequently, creates a new way of life in the present.

What can we conclude from the debates of the twentieth century concerning the kingdom of God? On the one hand, the divine reign is related to Christ's first advent. In a sense it is a reality that people can enter (Mark 9:47, Matt. 21:3132). It is the kingly power of God (Marcus, 1988:663-675). Hence, the kingdom is a 'sphere of existence' in which people are called to live. It is an incorporation into God's powerful invasion of our world; as such it consists in doing the will of God (Matt. 6:10; 7:21-23) and demands a radical decision (Matt. 13:44-46). To enter the kingdom means to participate in "the already inaugurated explosion of God's power into the world", to cite the words of Joel Marcus (Marcus, 1988: 674). On the other hand, the consummation of the divine reign awaits the glory surrounding Christ's second advent. One day all creation will be brought into conformity with the divine intent. Only then will the kingdoms of this world truly 
become the kingdom of God and God's will truly be done on earth as it is in heaven.

The concept of the eschatological kingdom as the future of the world and its presence in the here-and-now stands as an important theological motif, an illuminative and integrative theme for theological reflection ${ }^{3}$ and action in the world.

Despite the appropriateness of the motif of the kingdom of God, this concept alone is insufficient to provide the unifying centre for a Westem evangelical theology in a global context. Kingdom theology suffers from at least one debilitating flaw: it employs as its integrative motif a concept which remains undefined, a 'shell-word'. Hence, the focus on the kingdom raises foundational questions which beg to be answered: What is the kingdom of God that is coming and is already present among us? What does it mean to speak of the reign of God? What is the experience of the rulership of God? What is the significance of Jesus' prayer, "Your kingdom come, your will be done?" In short: What is the world like when it is transformed by the in-breaking of the kingdom?

Moreover, kingdom theology is all-to-readily coopted by the Westem mindset. In so far as the concept is left devoid of content, the kingdom idea readily leads to a theology taken captive by one of the destructive characteristics of the Westem 'spirit of the age', the emphasis on a radical, unbiblical individualism. Hence, a theology of the kingdom can easily degenerate into an individualistic theology - a theology that exalts and undergirds the radical individualism of the modern era.

Westem society, especially in North America, is indeed imbued with individualism. The ethos of modern living elevates and celebrates the unencumbered self, not always realizing that this concept is derived from modem philosophy, especially the legacy of Descartes, Locke and Hume. The elevation of the self is noticeable, for example, in our tendency to define ourselves fundamentally in terms of the choices we make, revealing thereby our proclivity to see ourselves as individual, autonomous, self-determining subjects. The autonomous self of the Westem myth supposedly exists independently and entirely outside of any tradition or community, although the self may choose voluntarily to join some community. According to Robert Bellah and his associates, writing in their seminal study Habits of the Heart, for most North Americans the meaning of life is "to become one's own person, almost to give birth to oneself" (Bellah et al., 1985:82). Hence, our society encourages us to "cut free from the past, to define our own selves, to choose the groups with which we wish to identify" (Bellah $e t$ al., 1985:154).

In the 1960s J Moltmann and W Pannenberg were influential in focusing attention on the umportance of the concept of the kingdom of God See Molemann, 1967, Pannenberg. 1969 
The unencumbered, autonomous self also forms the foundation for the social orders, all of which we tend to view from the vantage point of social atomism. The modern conception of the political order, for example, is based on the idea of the 'social contract'. According to this theory, autonomous selves come together to form the state, contracting with each other to give up a certain amount of their personal prerogatives to the whole for the sake of personal advantage.

Nineteenth century liberalism fell prey to the danger of becoming an individualistic theology of the kingdom. By defining the kingdom in terms of the ethical society of persons of good will founded by Jesus, liberal theologians were able to focus their gaze on the social dimension of the kingdom. Nevertheless, liberalism was unable to overcome the legacy of Schleiermacher, whose theology began with the God-consciousness of the individual, so that its 'society of persons of good will' was in the final analysis little more than an aggregate of individuals.

The situation did not improve greatly with the advent of the twentieth century. On the contrary, the theological outworking of the rediscovery of apocalyptic only exacerbated the problem. When read within the context of Western individualism, the eschatological new order anticipated by the ancient apocalypticists could make no convincing claim for the necessity of a social dimension.

\section{The contemporary appeal of community}

There are signs, however, that in the West the fascination with individualism is beginning to wane. The human sciences, for example, reveal a groundswell of interest in the concept of community, as a variety of thinkers are realizing that our understanding of the human phenomenon must reflect a more adequate balance between the individual and social dimensions (Helminiak, 1988:37). The current discussion has led to a new proposal for the relationship between the individual and society, called communalism or culturalism. ${ }^{4}$ The precursors of the newer model include some of the most prominent thinkers of the early twentieth century (for a summary of the phenomenological analyses of human solidarity, see Helminiak, 1988:37-44).

Among the seminal voices calling for an emphasis on community were the turnof-the-century philosophers Charles Peirce (1839-1914) and Josial Royce (18551913) (for a summary of the importance of Royce, see Oppenleim, 1989:87-119.) In The Problem of Christianity (1913) Royce explored the idea of one, vast 'community of interpretation', not so much as a present reality, but as a task to which we ought to be loyal. Anticipating contemporary writers such as Robert Bellah, he spoke of community in religious terms - as a community of memory

4 Culturalism is the term preferred by critic of the movement Robert J McShea (see Mc-

Shea, 1990:89-148). 
and hope, of faith and redeeming grace (for a short overview, see Reese, 1980:498-499).

But perhaps more influential has been the work of the social scientists. The French sociologist Emile Durkheim (1858-1917) set forth the idea that the group functions as the origin of the ideals of individuals. He argued that rather than preceding collective life, the division of labour can arise only in the midst of a society. Social cohesion, he theorized, is facilitated by 'collective representations', the group-based symbols with which individuals identify. Hence, a prerequisite to social diversification is a 'conscious collective', a pre-given solidarity of shared meanings and values (Durkheim, 1964:227). The function of religion, in turn, is related to the symbols by which a people articulate their shared meaning and value. By providing such symbols, religion creates and maintains social solidarity.

The work of George Herbert Mead (1863-1931) held much in common with that of Durkheim. He asserted that meaning is no individual matter but rather is interpersonal or relational. Hence, the inind is not a mere individual, but also a social phenomenon (Mead, 1934:123). And the self, the maturing personality, or one's personal identity, is socially produced (Mead, 1934:138-58). These considerations led Mead to conclude that the individual is not sui generis. Instead, human development is a product of the process of social interaction, for the mind, critical thinking, and a sense of self are facilitated by participation in the social group.

Building on the work of these pioneers, late twentieth century communalists argue that the fundanental short-coming of the radical individualism of the West is its disregard for the social dimension of life and for the importance of that dimension in the shaping of the self (see, for example, Bellah et al., 1985:84). In contrast to radical individualism, the communalists emphasize the importance of the social unit - the community - for certain crucial aspects of human living.

The community is integral to epistemology (the process of knowing). Communalists argue that we can no longer hold to the moden epistemological paradign which focuses on the self-reflective, autonomous subject. Rather, central to the knowing process is a cognitive framework mediated to the individual by the community. In keeping with this critique, contemporary social theorists are seeking to replace the individualistic foundational rationalism of modern Westem thinking with an understanding of knowledge and belief that views them as socially and linguistically constituted (see Lindbeck, 1990:495).

Similarly, the community is crucial to identity formation, communalists assert. Critics of individualism argue that a sense of personal identity develops through the telling of a personal narrative. Hence, finding ourselves means, among other things, finding the story in terms of which our lives make sense (Bellah et al., 
1985:28). Communalists declare that the narrative of a person's life is always embedded in the story of the communities in which the person participates (Macintyre, 1984:221), for traditions mediated by communities, and not individuals, are the carriers of rationality. The transcending story is mediated to the individual by the community, which transmits from generation to generation and from group to individual its traditions of virtue, common good and ultimate meaning (Bellah et al., 1985:495).

Although epistemology and identity formation form primary examples, contemporary communalists argue that community is also crucial to the sustaining of character, virtue and values. Consequently, it provides the necessary foundation for involvement in public discourse concerning matters of world view. Thus, beyond its role in the formation of individual identity, community is also crucial to the well-being of the broader society.

In short, communalists argue that a society is not merely an aggregate of individuals. Instead, foundational to society are the communities which transmit traditions from one generation to another (Bellah et al., 1985:282).

Bellah et al. (1985:72) offer an important cautionary word, however. We must avoid confusing community with what they perceptively term a "lifestyle enclave". Lifestyle enclaves are segmental, involving only a segment of each individual - namely, the private life, especially leisure and consumption - and including only those with a common lifestyle. In other words, a lifestyle enclave is a group of persons who are united merely by shared interests and activities. A community, in contrast, "attempts to be an inclusive whole, celebrating the interdependence of public and private life and of the different callings of all" (Bellah et al., 1985:72).

Nor is community to be confused with the older strand of North American thought that sees social life as merely an arrangement for the fulfilment of the needs of individuals. This view is found in the contemporary "therapeutic" conception of "communities of interest", groups of self-interested individuals who join together to maximize individual good (Bellah et al., 1985:134).

In steering us away from these mistaken notions, Bellah and his associates offer a helpful starting point. A community, they write, "is a group of people who are socially interdependent, who participate together in discussion and decision making, and who share certain practices ... that both define the community and are nurtured by it" (Bellah et al., 1985:333).

A genuine community is oriented toward the past, the future, and the present. Through this threefold orientation it constitutes the 'self' of its members. 
The past orientation of a community allows us to speak of a 'community of memory', to build from the thought of Josiah Royce. A community has a history - in fact, it is in an important sense constituted by its past. Consequently a community does not forget the past. Rather, to keep the past alive a community retells its story - its constitutive narrative - and thereby offers examples of those persons who have embodied and exemplified the meaning of the community. In addition a community tells stories of shared suffering and even of past evils (Bellah et al., 1985:152-155).

A community does not only turn its members toward history, however. Its gaze is also fixed on the future, and thereby it becomes a community of hope. It anticipates the continuation of, and even further development of the community that awaits it in the future. The community senses that it is moving forward toward an ideal which lies yet before it.

By looking at the past and the future, a community provides a transcendent vantage point for life in the present. It supplies a context of meaning that can allow its members to connect their personal aspirations with those of a larger whole. It facilitates them in seeing their efforts as being contributions to that whole.

Through its interest in the grand sweep of history, a community gives a qualitative meaning to life, to time and space, and to persons and groups. It is especially fitted for this task, in so far as it does not view time merely as a continuous flow of qualitatively meaningless sensations. By punctuating the day, the week, the season, the year with a sense of the sacred, a community presents time as a meaningful whole (Bellah et al., 1985:282). A community also perpetuates "practices of commitment". These define the community way of life and the patterns of loyalty and obligation that keep the community alive (Bellah et al, 1985:152-154).

\section{Community as an integrative theological motif}

The human sciences are moving beyond the radical individualism of the modem era to an understanding which seeks to strike a balance between the individual and social dimensions of the human phenomenon. This development suggests that theology must make a corresponding move. We must journey beyond the focus on the kingdom, which typified the past orientation of theology, while not leaving the insights of kingdom theology behind. Into the reigning kingdom theology, I would argue, we must incorporate the motif of community as defining the nature of God's reign. In so doing we can fill the concept of the kingdom of God with its proper content.

Community is important as an integrative motif for theology not only because it fits with contemporary thinking about the world and the human phenomenon in 
the world, but more importantly because it is central to the message of the Bible. From the narratives of the primordial garden, which open the curtain on the biblical story, to the vision of white-robed multitudes inhabiting the new earth, with which it concludes, the drama of the scriptures speaks of community.

But can we say more about the nature of the community God is seeking to bring to pass? Taken as a whole the Bible asserts that God's program is directed to the bringing about of community in the highest sense of the word - a reconciled people from all nations, living within a renewed creation, and enjoying the presence of their Redeemer God. In other words, God's program leads to nothing short of a global community.

The vision of community as spelled out in the biblical drama begins in the past. God's intent is articulated already in the Genesis 2 narrative, as God notes, "It is not good for the man to be alone". The divine activity throughout history is directed toward the bringing into being the community envisioned by the Creator who was cognizant of the solitariness of the first human in the Garden of Eden.

Central to the divine purpose of establishing community is the presence of God among his people. God's presence is a constant theme of the Bible. At the beginning, the Lord communed with Adam and Eve in the Garden. Then at various times and in various locations the patriarchs experienced the presence of God. To commemorate their encounters with him they built landmarks, altars, and memorials (e.g., Gen. 28:13-17). With a view toward the establishment of community - God dwelling with his people - Yahweh elected and entered into covenant with Israel. His intent was evident in the Exodus experience. The immediate goal of God's deliverance of Israel from the bondage of Egypt was the assembly of the people at Sinai. There Yahweh brought the Israelites into his presence, in order that they might be constituted as his people (Ex. 20:2-3), in whose presence he himself would come to dwell. During the wilderness sojourn, God intended to make his abode among them in the tabernacle; like theirs, his house would be a tent. So important was the divine presence among Israel that when Yahweh proposed that the tabernacle not be built because of Israel's sin, Moses responded, "If your Presence does not go with us, do not send us up from here" (Ex. 33:15) (Clowney, 1987:25-26). Later when Israel established fixed dwellings in the promised land, God also put his glory within a house, the temple in Jerusalem.

The Old Testament experience forms the context for the significance of Jesus Christ as Immanuel - God with us (Matt. 1:22-23). In Jesus, the divine Word became flesh and "tabernacled" among us (John 1:14) - that is, in him God is present with humankind. Jesus promised that both he and the Father would take up their dwelling with his disciples (John 14:23); in this context he spoke of another Comforter who would be present among his disciples (John 14:23). 
Jesus' promise, understood within the context of the Old Testament hope, forms the foundation for the work of the Spirit. Since his outpouring at Pentecost, the Holy Spirit facilitates the fulfilment of Jesus' promise of his continual presence with his followers. The Holy Spirit comprises them as the temple of God. Because of the finished work of Christ and the continuing work of the Holy Spirit, therefore, God himself is indeed among his people.

Yet, even our experience of God's presence with us is only partial. Indeed, the grand fulfilment of God's program lies yet in the future. The biblical story does not end with Pentecost and hence not with the true, yet partial experience of the presence of God currently enjoyed by Christ's disciples. The drama of the Bible stretches from the past into the future, reaching its climax with the grand vision of the new heaven and new earth.

The future renewed creation was anticipated by certain Old Testament prophets. This theme, however, is developed more fully by the closing chapters of the book of Revelation. The inspired seer looked to an era beyond the present which will mark the completion of the divine program in human history. He pictured the new order as the new Jerusalem (Rev. 21:9-21). In that city, the peoples of the new earth will live together in peace. Nature will again fulfil its purpose of providing nourishment for all earthly inhabitants (Rev. 22:1-4). Most glorious of all, however, God will dwell with humans, thereby bringing to completion the ultimate divine design for creation:

And I heard a loud voice from the throne saying, "Now the dwelling of God is with men, and he will live with them. They will be his people, and God himself will be with them and be their God ...". The throne of God and of the Lamb will be in the city, and his servants will serve him. They will see his face, and his name will be on their forehead (Rev. 21:3; 22:3-5).

Hence, the future new order will be characterized by community in the fullest sense. The participants in the eschatological reality, comprising people from every comer of the globe, will live in fellowship with each other, with creation, and most importantly with God.

John's vision of a future aeon characterized by a new community of reconciliation, fellowship and harmony confirms the assertion that the establishment of community lies at the heart of the concern of the Bible. God's ultimate intention is not directed to a transpositioning of the individual believer to an isolated, individual realm of unending 'eternal life' beyond the world. Rather, God's program focuses on the corporate human story and therefore on humans as potential participants in a new society in the coming aeon. In fact, scripture consistently presents our eternal home in social, rather than in individual terms. It is a great city, it encompasses many dwelling places, it is composed of a multitude of in- 
habitants, etc. Hence, it is a social reality. As Paul Hanson (1986:510) notes from his study of the theme of community in the Bible,

God's future reign was not construed in terms of a blissful union of the elect with God that removed them from the world of humanity, but as a reign of justice and peace that repaired all wounds and restored righteousness as the standard among humans.

The vision of the scriptures is clear: the final goal of the work of the triune God in salvation history is the establishment of the eschatological community - the one redeemed people of all the nations of the world dwelling in a renewed earth a renewed globe - enjoying reconciliation with their God, fellowship with each other, and harmony with all creation. This goal of a global community lies at the heart of God's actions in history.

The social nature of God's intent is displayed likewise in the focal point of salvation history, the Christ event. Jesus came as the exemplar human being, the revelation of who we are to be. And the divine design revealed by Jesus focuses on our living in relationship with God and with others. Jesus also came as the Messiah - a social figure, the fulfilment of the hopes and aspirations of the Hebrew people, and by extension of all humankind. In the same way, his intent was not to accomplish an individual vocation for his own sake, but to be obedient to the will of the Father for the sake of humankind. Thus, in his death he took upon himself the sins of all. And he rose from the grave in order to mediate to us eternal life through our union with him.

The work of the Holy Spirit likewise has the establishment of community in view. His outpouring at Pentecost was directed toward the establishing of the corporate body of Christ to be the one new people composed of Jews and gentiles reconciled to each other (Eph. 2:11-22). During the present age the Holy Spirit is bringing together a people that transcends every human division - a people from every nation and every socio-economic status, and consisting of male and female.

\section{The present reality of the eschatological community}

The completed work of Christ and the present work of the Spirit indicate that the eschatological community which arrives in its fullness only at the consummation of human history is already present among us in a partial, yet genuine manner. This present reality is to be experienced in many ways, but its focal point is the community of the followers of Christ - the church. The Christian church is a distinctive body formed by the Holy Spirit through the life, death and resurrection of Jesus (see for example McClendon, 1986:209-39). It is a community of faith which transcends spatial and temporal boundaries. 
The New Testament writers, such as Paul, declare that to be a Christian means fundamentally to be united with Christ. This union entails not only mental assent to a set of doctrines, but also the embodying in one's beliefs, attitudes and actions the meanings and values that characterized Jesus' own life. In this process of embodiment the Christian faith-community is crucial. The believing community transmits from generation to genleration and region to region the redemptive story, which it recounts in word and deed. In so doing, it mediates to the believer the framework for the formation of personal identity, values and world view.

Through their loyalty to Christ and within the context of the faith community, Christians enjoy a common life marked by their unity with Jesus. In this common life they seek to be a true community of faith, which they manifest in corporate worship, mutual edification and outreach to the world. The worship dimension focuses the attention of the believing community on the One who constitutes them as his people. Through the corporate worship life, the community also gathers to commemorate the foundational events of their spiritual existence, at the centre of which is the action of God in Christ delivering humankind from the bondage of $\sin$ in its many fonns.

The dimension of edification means that the corporate people take seriously their existence as a fellowship of mutuality. Community therefore means that we sense our oneness with each other. We enter into a relationship of sympathy, compassion and empathy. We interceed for each other, care for each other and minister to the needs of each other. The demands of the life of discipleship in a fundamentally inhospitable environment heighten the importance of mutuality. We desperately need the support of others who share the same vision of God's actions in the world and who are also dedicated to participation in the divine activity.

No true community of faith, however, can fail to direct its sights outward toward the world in which it is called to live. Foundational to its existence is a vision of the whole human family reconciled to God, to one another and to creation. Consequently, it directs its energies toward those who lie beyond its membership, seeking to proclaim and embody the gospel and to minister to the hurts of needy people. A community of faith also holds up before the world the sovereign God as the only hope and the only sure and worthy alternative to the myriad of competing loyalties which despite their lure fall short of ultimacy.

At the centre of the transmission of the redemptive story as it has worked itself out in the life of the believing community is the Bible, the book of the church. The Bible remains central to the faith and life of the contemporary believing community exactly because we see ourselves as an extension of the biblical community of faith. This book is in effect our spiritual autobiography (Hanson, 1986: 537), tracing the birth, pilgrimage and vision of the ancient faith community in which we participate and of which we are heirs. Consequently, we study the 
scriptures in order to discern what it means to be the community of faith, and hence what it means to be the community of faith today.

Related to the biblical proclamation are the rites of the community, specifically baptism and the Lord's supper. These two sacraments reenact the story of redemption - both as they memorialize the events of Jesus' passion and resurrection and as they bear testimony to the experience of union with Clirist shared by the entire community.

Baptism marks the initiation of the individual into the narrative of the Christian community. This practice inducts the new believer into the shared practices of the community which is defined and ruled by the story of Christ's life, death and resurrection (Jones, 1990:137-139). The church, therefore, rightly sees in baptism the symbol of the new birth and the new identity that the church has received, for baptism represents the change of context that has brought the new believer into the family of God. Because we enjoy a new identity, we no longer define our lives in accordance with the categories of the old life. Rather, we see ourselves as those who have passed from the rulership of $\sin$ and its condemnation into the people of God, who are reconciled with their Lord and Saviour, and therefore who seek to live in reconciliation with each other. The new identity symbolized by our baptism, therefore, carries ethical demands. We are called now to live out ir our conduct the new identity God has frecly bestowed on us, i.e., that we be the one community of God in and for the world, which we are.

What is initially declared in baptism is repeatedly articulated by the other rite of the church, the Lord's supper. By our participation in this sacrament, we are reminded of our identity in Christ, our covenant with God and one another, and the resultant ethical demand that we live 'unto the Lord'. As we sit together at the Table, we are repeatedly reminded of our calling to be the one church of Christ living for the glory of God in the midst of the one earth - which is God's earth and the one world - which God in Christ has claimed for his own.

\section{Conclusion: The kingdom is 'community'}

A theology in the context of the reality of globalization orients its discussion of the Christian faith around the twin motifs of the reign of God and the community of God. The Bible presents history as meaningful, in that it is directed toward a goal - namely, the kingdom of God or the permeation by the will of God of the whole earth and of all human affairs. This goal fonns the central petition of the Lord's Prayer: "your kingdom come, your will be done on earth as it is in heaven" (Matt. 6:10).

Rather than a rejection of this lofty concept of the kingdom of God, the incorporation of the idea of community as an integrative motif for theology fills the 
concept with its proper content. When God's rule is present, i.e., when God's will is done, community emerges. Or viewed from the opposite direction, in the emergence of community, God's rule is present and God's will is accomplished.

As it is called by God to exist in the world, the community of faith is, in fact, a laboratory of the kingdom. It seeks to embody the vision of God's new order, it seeks to reflect those qualities that it infers from God's activities on behalf of creation. As a people who have experienced God's gracious deliverance from bondage and God's gracious reconciliation to himself, we are free to show forth the nature of the liberating God and thereby give witness to the state of affairs that characterizes the in-breaking of God's reign.

The kingdom of God, therefore, is the vision of God's ruling presence that redeems, reconciles, and transforms creation into God's intended ideal and constitutes the world as God's realm. It both transcends history and works within history as both the paradign of the new order and the power effecting that order. It is, in the words of Peter Hodgson, "the way God acts redemptively, efficaciously in the world" (Hodgson, 1987:226). This biblical vision, however, is communal or social in scope. In its communal nature it is also global in scope, directed toward the world as a whole. The kingdom of God is characterized by community. It is present wherever the new society of reconciliation is created that people who have entered into covenant with the God of history and consequently live out their covenantal life through worship of the God revealed in Christ, mutual care and mission in and for the entire world.

Western evangelical theology must catch this vision of the new community God is seeking to create among us. Only by so doing it can overcome the individualism that has plagued evangelicalism in this century. But in catching this vision, Western evangelical theology will also discover that it is being linked to insights that lie at the centre of theological expressions of the gospel found in other regions of the one world we share in common.

\section{Works cited}

BELLAH, Robert N., MADSEN, Richard, SULLIVAN, William M, SWIDLER Ann \& TIPTON, Steven M 1985 Habits of the Heart: Individualism and Commitment in American Life Berkeley: University of California Press

BERG, Marcus J 1987. Jesus and the Kingdom of God Christian Cenlury, 102(13):378-80, April 22

BLAISING, Craig A \& BOCK, Darrell L 1992 Dispensationalism, Israel and the Church Grand Rapids, MI : Zondervan

CASTRO, Emilio 1985 Freedom in Mission : The Perspective of the Kingdom of God - An Ecumenical Inquiry Geneva : World Council of Churches Publications

CHAFER, Lewis Sperry 1947-48 Systematic Theology 8 volumes Dallas : Dallas Seminary Press

CHILTON, Bruce D 1984 Introduction in "The Kingdom of God in the Teachings of Jesus". Isswes in Religion and Theology 5. Philadelphia Fortress. 
CHILTON, Bruce D. 1987. God In Strength: Jesus' Announcement of the Kingdom Reprinted Edition. Shefield, England : JSOT

CLOWNEY, Edmund P. 1987. The Biblical Theology of the Church (In Carson, D.A., ed.

The Church in the Bible and the World. Grand Rapids, MI : Baker, p. 25-26.)

COBB, John, Jr. 1965. A Christian Natural Theology. Philadelphia : Westminster.

CONE, James H. 1970 A Black Theology of Liberation. Philadelphia : J.B Lippincott

DURKHEIM, Emile. 1964. The Division of Labor in Society. George Simpson, trans. New York : Macmillan.

ERICKSON, Millard J. 1983-85. Christian Theology. 3 volumes. Grand Rapids, MI : Baker

FACKRE, Gabriel. 1984. The Christian Story. Grand Rapids : MI : Eerdmans.

GOLDBERG, Michael. 1982. Theology and Narrative. Nashville : Abingdon.

GRENZ, Stanley J. 1992 "Community" as a Theology Motif for the Western Church in an Era of Globalization. Crux, 28(3):10-19, September.

GRENZ, Stanley J. 1992. The Millennial Maze: Sorting out Evangelical Options. Downers Grove, IL : InterVarsity.

GRENZ, Stanley J. 1993. Revisioning Evangelical Theology Downers Grove, IL : InterVarsity.

GUTIERREZ, Gustavo. 1980. A Theology of Liberation Maryknoll, New York : Orbis

HANSON, Paul D. 1986. The People Called San Francisco: Harper \& Row

HELMINIAK, Daniel A. 1988. Human Solidarity and Collective Union in Christ Anglican Theological Review, 70(1) 37 .

HOEKEMA, Anthony, 1979. The Bible and the Future. Grand Rapids, MI : Zondervan

HODGSON, Peter C 1987. Ecclesia of Freedom Theology Today, 44(1):226

HORDERN, William E 1968 A Layman's Guide to Protestant Theology Revised Edition New York : Macmillan.

JONES, L. Gregory. 1990. Transformed Judgement: Toward a Trinitarian Account of the Moral Life. Notre Dame : University of Notre Dame Press

LINDBECK, George A 1990. Confession and Community: An Israel-like View of the Church. Christian Century, 107(16):495, May 9.

MACINTYRE, Alisdair 1984 After Virtue Second Edition. Notre Dame : University of Notre Dame Press

MADDOX, Randy L 1984. Responsible Grace: The Systematic Perspective of Wesleyan Theology. Wesleyan Theological Journal, 19(2) 12-18, Fall.

MARCUS, Joel. 1988. Entering into the Kingly Power of God Journal of Biblical Literature, 107(4) 663-675.

McCLENDON, James William. 1986. Ethics: Systematic Theology. Volume One Nashville : Abingdon

McSHEA, Robert J. 1990. Morality and Human Nature A New Route to Ethical Theology Philadelphia : Temple University Press.

MEAD, George Herber. 1934. Mind, Self and Society Charles W. Morris, ed (Reprint Edition 1974 Chicago : University of Chicago Press.)

MOLTMANN, Jurgen 1967. Theology of Hope. Trans. James W Leitch London SCM

OPPENHEIM, Frank M 1989. A Roycean Response to the Challenge of Individualism: Toward a Retrieval of Moral Discourse in America. Notre Dame University of Notre Dame Press.

PANNENBERG, Wolfhart. 1969. Theology and the Kingdom of God. Philadelphia : Westminster.

REESE, W.L. 1980. Dictionary of Pjilosophy and Religion. Atlantic Highlands. NJ : Humanities Press

RUETHER, Rosemary Radford. 1983. Sexism and God-Talk Boston: Beacon. 
SAUTER, Gerhard \& SYOCK, Alex 1976. Arbeitswesen Systematischer Theologie . Eine Leitung. Munich : Kaiser

STROUP, George W. 1973. The Promise of Narrative Theology. Atlanta : John Knox.

SUCHOCKI, Marjorie Hewitt 1984 God, Christ, Church New York : Crossroad

WEISS, Johannes. 1892. Jesus' Proclamation of the Kingdom of God. Richard H. Hiers \& Daniel L. Holland, trans. Philadelphia : Fortress. 
